\title{
Globalisation Of Women's Rights Norms: The Right To Manifest Religion And 'Orientalism' In The Council Of Europe
}

\author{
Dr. Charlotte Skeet
}

\begin{abstract}
Women's access to and enjoyment of human rights is increasingly being used as a global measure of other 'goods' in societies, for instance as a measure of development, a gauge of the health and depth of democracy and as a general indicator of a state commitment and adherence to international responsibilities. Therefore, while the study of women's relationship to human rights is of considerable importance and interest in itself it is also gaining prominence across a range of other areas of international and domestic law. This might be viewed as a positive indication of the growing strength of women's human rights norms but it bears closer analysis. Also, a question remains as to what rights norms are being globalised and how this is occurring within the discourse on women's rights.

This paper considers how apparently universalist rhetorics around equality rights can advance 'orientalist' and patriarchal discourses in relation to who 'women' are and how their rights may be realised. Such discourses may hinder implementation of women's rights, especially for women who are 'other.' This is particularly evident in relation to women's rights to freedom of expression, the manifestation of religious freedom and rights to participate in culture. Therefore, specific focus is given to the increasing discrimination against Muslim women and on human rights responses in this context within Europe.
\end{abstract}

\footnotetext{
* Dr Charlotte Skeet is a Lecturer in Law and Gender Studies at the University of Sussex
}

Public Space: The Journal of Law and Social Justice (2009) Vol 4, pp 34-73 


\section{I - Introduction}

Sixty years after the Universal Declaration of Human Rights, and following hard campaigning by women's groups, women's rights appear to have become popular currency. Women's access to and enjoyment of human rights are increasingly being used as global measures of other 'goods' in societies, for instance as a measure of development, ${ }^{1}$ a gauge of the health and depth of democracy ${ }^{2}$ and as a general indicator of state commitment and adherence to international responsibilities. ${ }^{3}$ The apparent mainstreaming of concern with gender might be viewed as a positive indication of the growing strength of women's human rights norms, but it bears closer analysis. Discourses around women's rights are now being generated in institutions by jurists and policy makers who do not demonstrate a rigorous feminist analysis in relation to equality. Is the focus on women's autonomy and enjoyment of human rights as goods in themselves or rather as generators of income or progenitors of modernity $?^{4}$ Even within feminist movements, considerable debate occurs around understandings of equality and the questions of what approaches should be adopted for the realisation of women's rights. In this climate, when there is no clear consensus, what discourses around women's rights norms are being globalised and what is their impact?

This paper offers some reflections on the way that human rights discourses may in effect advance and support orientalist and patriarchal discourses in relation to who 'women' are and how their rights may be realised. In particular, it illustrates how jurisprudence from the European Court of Human Rights (and other Council of Europe) institutions has fostered orientalist discourses which are detrimental to women. This is particularly clear in relation to the freedom to manifest religion. In a global context there has been less attention paid to freedom of religion compared with

\footnotetext{
${ }^{1}$ See, e.g. World Bank, Engendering Development: Through Gender Equality in Rights, Resources and Voice (2001)World Bank Washington,1; Genevieve Painter, 'Linking Women's Rights and MDG's: An Agenda for 2005 from the Gender and Development Network'(2005) 13 (1)Gender and Development 79 ..

${ }^{2}$ See, e.g. Zo Randriamo, 'African Women Challenging Neo-Liberal Economic Orthodoxy: The Conception and Mission of the GERA Programme'(2003) 11(1) Gender and Development 44.

3 See, e.g. DFID (Department for International Development), Realising Rights for Poor People (2000), DFID, London.13; World Bank, above n1.

${ }^{4}$ See, Painter, above n1.
} 
other human rights and civil liberties and the role of freedom of religion in "conflicts and maintaining political order' has been comparatively neglected. ${ }^{5}$ Despite this relative lack of attention clear gender differences can be seen in the way that this right is discussed and applied. When claimed by women, 'freedom to manifest religion' has become a locus for conflicting feminist positions and clashing rights discourses and these claims provide a useful illustration of the failure to apply women's rights to all women in a context of dominant Western cultural norms.

The next section (II) of this article defines the theoretical basis of the paper and explores the conflicts and intersections between globalisation, orientalism or neoorientalism and feminism. Section III considers the history of Article 9 adjudication in the Council of Europe rights system and analyses Leyla Sahin v Turkey, ${ }^{6}$ a case which exemplifies the problems of orientalism in human rights discourses. Section IV both locates the Sahin decision within the wider human rights framework provided by non-governmental organisations (NGO's) and international bodies and provides an analysis which goes beyond jurisprudential issues to show the consequences of rights discourses on women's rights as lived experience. Section V offers some conclusions from this discussion.

\section{II - Globalisation, Feminism And Orientalism}

This section explores the interrelationship between the globalisation of women's rights, feminism, and orientalism in rights discourse. Orientalism can be described as a set of discourses which present the Orient in negative terms and as 'other' in relation to the West. From the 17th Century there was a particular curiosity about Islam and the East in Europe, in the 18th and 19th Centuries study became increasingly hostile. ${ }^{7}$ Although discourses were generated by a variety of different media, literature, art and

\footnotetext{
${ }^{5}$ Paul Marshall, 'Religious Freedom' in Liam Gearon (ed.) Human Rights and Religion: A Reader. (2002) Sussex Academic Press, Brighton. 356.

${ }^{6}$ Leyla Sahin v Turkey (Application no 44774/98) to Grand Chamber Strasbourg at 10 January 2006, http://portal.coe.ge/downloads/Judgments/LEYLA SAHIN v TURKEY.pdf

7 Ann Thompson, Barbary and Enlightenment: European Attitudes Towards the Maghreb in the Eighteenth Century (1987) Brill, Leiden.
}

Public Space: The Journal of Law and Social Justice (2009) Vol 4, pp 34-73 
other disciplines, the discourses share an 'intellectual authority over the orient within Western culture ${ }^{8}$ and they tend to portray Islam as backward, alien and monolithic.

This historical construction of the identity of the East (particularly the Middle East) and Islam is itself a variant of binary colonial discourse which systematically conditioned knowledge and understandings of non-Western peoples as 'other' and inferior, against a positive construction of the West. These binary colonial discourses had a particular fascination with the treatment of women in other societies. Both the greater independence of women in some non-Western societies and any indications of the supposed low status of women in these other societies were seen as indications of that society's pre-modern barbarism. ${ }^{9}$ When applied to women orientalist perspectives portrayed them in non-Western cultures as victims situated within monolithic social structures hostile and oppressive to women ${ }^{10}$ on the one hand whilst on the other as being dangerously erotic, ${ }^{11}$ threatening carriers of a culture which is 'other.'

In debates about the nature of globalised rights movements, distinctions are sometimes drawn between economic globalisation with a neo-imperial ideology and the concept of globalisation as being a purely technical process descriptive of the increasing ease with which people can contact one another across the world. While it has frequently been argued that the former model of globalisation has been harmful to women, ${ }^{12}$ it is also argued that the latter processes are of benefit in developing a solid

\footnotetext{
${ }^{8}$ Edward Said, Orientalism: Western Conceptions of the Orient (1978), Penguin, London.19.

9 See, for instance, Gregory Massell, 'Law as an Instrument of Revolutionary Change in a Traditional Milieu: The Case of Soviet Central Asia' (1968) 2, Law and Society Review 179 for a discussion of this in the soviet imperial context and for the British colonial context; Ann McClintock, An Imperial Leather: Race, Gender and Sexuality in the Colonial Contest (1994) Routledge, London; Clare Midgely, (ed) Gender and Imperialism (1998) Manchester University Press, Manchester; Clare Midgely, 'British Women, Women's Rights and Empire, 1790 -1850' in Patricia Grimshaw, Katie Holmes and Marilyn Lake, Women's Rights and Human Rights in International Historical Perspective (2001) Palgrave, Basingstoke.

${ }^{10}$ Ratna Kapur, Erotic Justice: Law and the Politics of Postcolonialism (2005) Glasshouse Press, London.

${ }^{11}$ Meyda Yeğenoğlu, Colonial Fantasies: Towards a Feminist Reading of Orientalism (1998) Cambridge University Press Cambridge.

12 Josephine Kerr and Caroline Sweetman, 'Editorial,' (2003) 11 (1) Gender and Development 3-12, 4; Nilufer, Cagaty, 'Gender Budgets and Beyond: Feminist Fiscal Policy in the Context of Globalisation’ (2003) 2:1 Gender and Development: Women Reinventing Globalisation 15, 24. Conversely Naila Kabeer is critical of a portrayal of women only as victims of economic globalisation and argues for more complex analysis of the impact of global processes which take into the specific contexts and agency of women. See Naila Kabeer, 'Globalisation, Labour Standards, And Women's
} 
international movement for women's rights linking women all over the world. ${ }^{13} \mathrm{De}$ Souza Santos ${ }^{14}$ and Kerr and Sweetman ${ }^{15}$ suggest that a clear dualism exists within globalisation practices: on one hand a neo-liberal or corporate-led globalisation and on the other globalisations which are bottom up and counter-hegemonic, or rights led. ${ }^{16}$

Sceptical of any distinct dualism in globalisation processes, Richard Falk ${ }^{17}$ sees a 'creative tension' within international law. He argues that, on one hand international law can be viewed as the 'legal conception of a global normative order' and as such it acts as an 'instrument for the orientalist domination and exploitation of non-Western peoples of the world. ${ }^{18}$ Yet, he states, that, contemporaneously, international law may also be viewed as:

...a fragile yet indispensable, humanist enclave, which although embedded in realist and imperialist geopolitical behaviour provides the normative foundations for resistance against and emancipation from contemporary forms of imperialism. ${ }^{19}$

By phrasing it this way Falk makes it clear that we cannot completely distinguish socalled good or bad globalisations by the supposed purposes of the law or of global movements. Even human rights law and movements may be used to further domination and exploitation. Accepting that there can be such problems with rights discourses is not to deny the value of rights rhetoric and norms per se, but rather to insist that we interrogate the use and nature of rights discourses wherever they take place.

Rights: Dilemmas of Collective (In)Action In An Interdependent World' 2004 10(1) Feminist Economics 3.

${ }^{13}$ Kerr and Sweetman, above n12.

14 Bonaventura De Souza Santos and Cesar a. Rodriguez-Garavito, Law and Globalisation from Below, Towards Cosmopolitan Legality (2005) Cambridge University Press, Cambridge.

15 Kerr and Sweetman, above n 12.

16 A given illustration of a movement within this model is the World Social forum which De Sousa Santos and Rodriguez argue is driven by the twin conceptions of equality and respect for diversity. See above $\mathrm{n} 14$.

17 Richard Falk, 'Orientalism and International Law: A Matter of Contemporary Urgency' (2004) 7 (1-

2) The Arab World Geographer 103.

18 Ibid.

19 Ibid.

Public Space: The Journal of Law and Social Justice (2009) Vol 4, pp 34-73 
That rights may be used by dominant groups against political minorities is a persistent theme in the feminist critique of human rights. ${ }^{20}$ Emphasis has tended to be on the presentation of false claims of universalism which exclude women's experience. Feminists have highlighted the problem of individual rights claims by men and corporate rights claims by political or cultural groups which take precedence over, and are used to defeat, competing rights claims by women. Much Western feminist scholarship has been devoted to discussion and consciousness-raising in order that harms to women are not ignored or left out of rights frameworks in the name of deference to culture. $^{21}$

Debate within the feminist movement may initially have been driven by the perception of 'an uncritical consensus in relation to multiculturalism' ${ }^{, 22}$ and the very real difficulties of asserting women's rights as human rights. Ann Stewart recently suggested that 'legal feminism has largely moved beyond dichotomous debates such as those relating to universalism and relativism. We now have a much greater understanding of the way in which legal discourses contribute to the construction of identities. ${ }^{23}$ Yet the way some international women's movements, dominated by Western feminists, still frame campaigns and use law suggests that the feminist movement is not yet beyond neo-colonialism and orientalism. ${ }^{24}$ There may be greater awareness within the feminist movement of post-colonial critiques around women's rights discourse, but false universals in relation to the position of women continue to be presented. ${ }^{25}$ These presentations lead to an inability to grasp the complexity of meanings in the lives of women who are different or 'other' and hide the reality of rights breaches against women who are 'othered' within the category of women. ${ }^{26}$

\footnotetext{
${ }^{20}$ Katherine Bartlett and Rosanne Kennedy, Feminist Legal Theory: Readings in Law and Gender (1991) Westview Press, Boulder.

21 See the discussions by Susan Moller Okin, 'Feminism and Multiculturalism: Some Tensions.' (1998)108 (4). Ethics 661; and Eva Brems, 'Enemies or Allies?: Feminism and Cultural Relativism as Dissident Voices in Human Rights Discourse' (1997) 19(1) Human Rights Quarterly 136.

${ }^{22}$ Anne Phillips, Multiculturalism without Culture (2008) Princeton University Press, Woodstock,2.

23 Ann Stewart, 'Globalising Gender Justice?'(2007) 1 Law, Social Justice \& Global Development Journal (LGD) http://www2.warwick.ac.uk/fac/soc/law/elj/lgd/2007_1/stewart LGD 2007 (1) - Stewart at 1 October 2008.

${ }^{24}$ Kapur, above n10.

25 Ibid and see also Chandra Talpade Mohanty, 'Under Western Eyes: Feminist Scholarship and Colonial Discourses'(1984) 12 (3) Boundary 333.

${ }^{26}$ This paradox in women's rights discourse is what Ratna Kapur calls a logic of 'justification of exclusion through liberalism.' Kapur, above n 10.
} 
In relation to orientalism and women's rights, Roksama Bahramitash ${ }^{27}$ suggests that we can identify two positions: 'feminist orientalism' where orientalists use women's rights to legitimise neo-colonialist policies without necessarily having any concern for feminist positions, and 'orientalist feminism', where genuinely feminist discourses are presented in such a way that they support orientalist discourses. ${ }^{28}$ The distinction Bahramitash draws is useful because it shows the need to approach this in two ways; firstly that there is a need to expand the debate within feminism, secondly that irrespective of any need to broaden the debate feminists must urgently address the fact that 'outside of feminist circles, principles of gender equality [are] being deployed as part of a demonisation of minority cultural groups ${ }^{29}$ from which women are not exempt.

The invasion of Afghanistan after 9/11 provides an illustration of both feminist orientalist and orientalist feminist positions identified by Bahramitash. A number of women's groups, for instance the Revolutionary Afghanistan Women's Association (RAWA) and Women Living under Muslim Laws (WLUML), had been campaigning for years to raise the profile of women's rights breaches under the Taliban. ${ }^{30}$ Yet it was not until the events of 9/11 that concerns with women's rights breaches were apparently 'mainstreamed' in the foreign policy of the UK and USA. This is a clear example of 'feminist orientalism'. For while women's rights were held up as a justification for military intervention, ${ }^{31}$ there was actually little consideration of women's security in the course of the invasion and the subsequent occupation has

\footnotetext{
27 Roksana Bahramitash, 'The War on Terror, Feminist Orientalism and Orientalist Feminism: Case Studies of Two North American Bestsellers'(2005) 14:2 Critique: Critical Middle Eastern Studies 221. ${ }^{28}$ Charlotte Weber, 'Unveiling Scheherazade: Feminist Orientalism in the International Alliance of Women, 1911-1950' (2001) 27:1 Feminist Studies 125,127 suggests the term 'Feminist Orientalist' originates with Joyce Zonana in 'The Sultan and the Slave: Feminist Orientalism and the Structure of Jayne Eyre' in Clark et al (ed.) Revising the Word and the World (1993) University of Chicago Press, Chicago.

${ }^{29}$ Phillips, above n 22 at 2. Islam particularly has come under attack in international law and Western domestic policies in the later $20^{\text {th }}$ Century and especially post $9 / 11$ period. See for instance William Lafi Youmans, 'Edward Said and Legal Scholarship' 2004) 1073 UCLA Journal of Islamic and Near Eastern Law 1; Jean Allain, 'Orientalism and International Law: The Middle East as the Underclass of the international Order' (2004) 17 Leiden Journal Of International Law 391; Falk, above n 17.

30 Also under previous Western and Soviet backed governments in Afghanistan.

31 Jan Jindy Petmann calls these, 'Rights of Convenience.' See Jan Jindy Pettman, 'Global Politics and Transnational Feminisms,' in Luciana Ricciutelli, Angela Miles and Margaret McFadden Feminist Politics, Activism and Vision: Local and Global Challenges, ed.( 2005) Zed Books, London and New York 49-63.
} 
shown little substantial concern for women. ${ }^{32}$ Further, in what has proved to be an unwise alliance, many Western feminists who had campaigned against the Taliban supported the invasion - their position could be described as 'feminist orientalist'. Neither RAWA nor WLUML supported the invasion and are still campaigning against the occupation.

Another illustration of both feminist orientalist and orientalist feminist positions comes from the academic Sherene Razack who argues that whatever the substantive issues for debate in Canada around Sharia law there is a problem with the way the debate has been framed:

"Canadian feminists (both Muslim and Non-Muslim) have 'utilized frameworks that installed a secular/religious divide that functions as a colour line, marking the difference between the white, modern, enlightened West, and people of colour, and in particular, Muslims.",33

Neo-orientalism in women's rights discourse around Islam causes a number of problems at both a practical and theoretical level. From her work on the presentation of asylum claims and rights to refuge, Susan Akram has identified three principle ways that harm is caused. ${ }^{34}$ Firstly that stereotyping actually 'supports and promotes the most repressive and extreme versions of Islamic interpretation' because it allows fundamentalist regimes who manipulate such interpretation to 'further distance Islam from universal human rights. ${ }^{35}$ Secondly, by dividing promoters of human rights in the Islamic world from their counterparts in the West, it diminishes the potential of feminist and rights movements. Thirdly by privileging certain 'Western feminist' interpretations of rights breaches above more local understandings of the nature of those breaches, it may deny women the best expertise and reduce protection. While it

\footnotetext{
${ }^{32}$ See the Amnesty International Report 'Afghanistan' No One Listens To Us And No One Treats Us Like Human Beings: Justice Denied to Women'

http://www.amnesty.org/en/library/info/ASA11/023/2003 at August 2007 which charts a worsening in some cases.

33 Sherene Razack, 'The 'Sharia Law' Debate In Ontario: The Modernity/ Premodernity Distinction in Legal Efforts to Protect Women from Culture' (2007) 15 Feminist Legal Studies 3, 6.

34 Susan Mussarat Akram, S. M, 'Orientalism Revisited in Asylum and Refugee Claims' 2000) 12 International Journal of Refugee Law 7, 9.

${ }^{35}$ Ibid 9. Although Akram discusses this in the context of Islam the critiques could equally be applied to neo-orientalist discourse around any other culture or religion.
} 
is always necessary to take into account the context of rights breaches, orientalism 'fetishises' or 'eroticises' some harms to women and through this different treatment together with the development of a 'rhetoric of victimisation' women may be denied agency and a voice. ${ }^{36}$

Rather than just failing to adequately protect women, such approaches may actually imperil or thwart implementation of human rights norms. An example of problematic strategy is what Ali Tripp calls the international interventionist 'rescue' paradigm. Tripp argues that international groups sometimes intervene at a local level over the head of a local NGO even where the women at a local level specifically ask that they be left to direct resources and action. ${ }^{37}$ Such exoticising or fetishising of the role of the 'other' in relation to rights breaches tends to shift attention away from the wider geopolitics of inequality within national and international systems ${ }^{38}$ and may frustrate internal solutions by presenting culture or religion as insurmountable barriers to equality for women in these contexts. ${ }^{39}$ By failing to recognise an intersectional approach to discrimination it sometimes seems that women who are 'other' must first be separated from their religion and culture before they can be the recipients of equality. ${ }^{40}$

In this context the autonomy of the actual woman becomes a mute point. For example, Susan Akram details the reluctance of refugee advocates to present asylum claims where Muslim women have been persecuted because their understanding of Islam differs from that of the state. She notes that in these circumstances the women's claims have been presented as gender persecution when in fact they are based on political opinion (feminist or otherwise) or religion. She explains that, because of stereotypical views held by adjudicators on the capacity of Islamic women to act politically and a conception that Islam is monolithic, often, the true situation is not presented:

\footnotetext{
36 Kapur, above n 10,19.

37 An example is provided by the intervention in the case of Amina Lawal in Nigeria against the express wishes of local activists: See Ali Mari Tripp, 'Challenges in Transnational Mobilisation' in Ali Mari Tripp and Myra Marx Ferree (eds.) Globalism, Feminism: Transnational Women's Activism, Organizing and Human Rights (2006) NYU Press, New York, 299.

${ }^{38}$ Kapur, above n 10.

39 Razack, above n 33, 15.

40 Ibid.
}

Public Space: The Journal of Law and Social Justice (2009) Vol 4, pp 34-73 
[F]irst, because the applicant is given a choice of either denouncing 'Islam' altogether or foregoing her claim, her ability to express a different set of religious beliefs other than is practised by the government she flees is silenced; second, because, the government's actions are portrayed as being legitimately required by the religion itself, the applicant's opposition to such actions can never be seen as political and the political nature of her opposition is stultified. ${ }^{41}$

Focussing only on the gender of the applicants and ignoring other aspects of a woman's identity or positionality ${ }^{42}$ creates this incomplete picture. In contrast, I adopt a 'difference' approach which analyses discrimination not by attributing essential characteristics to women but instead by recognising how their positioning (unfavourably) compares with dominant norms of personhood. This approach must take into account characteristics other than sex where they also present a difference to the dominant norm. It therefore allows for differences among women and differences among Islamic women. In Inessential Woman: Problems of Exclusion in Feminist Thought, ${ }^{43}$ Elisabeth Spelman asks whether it is ' ... possible for us to think of a woman's 'womaness' in abstraction from the fact that she is a particular woman, whether she is a middle-class Black woman living in North America in the twentieth century or a poor white woman living in France in the seventeenth century... ${ }^{44} \mathrm{We}$ might add, in the context of the case study below, the example of an Islamic student manifesting her religion by wearing a headscarf to university.

\section{III - The Council Of Europe And Women's Freedom To Manifest Religion}

\footnotetext{
41 Akram, above n 34,26,27.

42 The term positionality, which is sometimes also referred to as 'ascriptive social perspective' or 'social group differentiation' is used by Iris Marion Young (see Iris Marion Young, Inclusion and Democracy,(2000) Oxford University Press, Oxford) and Melissa Williams (see Melissa Williams, Voice, Trust and Memory : Marginalized Groups and the Failure of Liberal Representation (2001) Princeton University Press, Princeton) to denote the external characteristics attributed to the concept of woman, race, class, religious group etc or any combination e.g. Islamic woman. This is quite separate from any characteristics that the group in question might use to define itself. Thus 'social positioning 'may be a facet or aspect of identity it can also be distinguished from identity.

${ }^{43}$ Elizabeth Spelman, Inessential Woman: Problems of Exclusion in Feminist Thought, (1988)

Beacon Press, Boston.

${ }^{44}$ Ibid 13.
}

Public Space: The Journal of Law and Social Justice (2009) Vol 4, pp 34-73 
The Council of Europe has delivered very positive leadership in setting rights standards and adjudicating rights claims in Europe in many respects. Yet within the Council of Europe's discussions on the rights of Islamic women orientalism is manifest. This is particularly clear in the cases around women's right to manifest religion, where the process of rights adjudication has been used as a tool of assimilation, rather than protection from discrimination based on difference.

Though it is a regional system, the Council of Europe is not just confined to influencing rights systems within Europe. It has a wide-ranging membership consisting of 47 countries. In addition observers from Israel, Canada, the United States, Japan, Mexico and the Holy See attend the Council of Europe Parliamentary Assemblies. As the first international court to allow individual petitions, the long ECtHR jurisprudence exercises considerable influence around the world. ${ }^{45}$ Pronouncements from this human rights institution are important not only because they influence the domestic laws and shape the cultural norms of the member states but because they are also open to assimilation, supplementation and adaptive interpretation by other domestic and international courts and governments. ${ }^{46}$

Problems with the approach of the Council of Europe can be seen both in the case law (and in the lack of it) and in resolutions from the Council of Europe Parliamentary Assembly - the Committee on Equality between Men and Women. There is criticism of this approach from within: individual authors like Renata $\mathrm{Uit}^{47}$ whose views are publicised through the Council of Europe and the resolutions and reports from the European Commission on Racism and Intolerance ${ }^{48}$ provide an alternative perspective and make a welcome contribution to debate in this area.

\footnotetext{
45 Note, for example, New Zealand's reluctance to dispose of the Privy Council as a final court because the Privy Council was considered o provide a link to the adjudication on the European Convention on Human Rights and Fundamental Freedoms.

46 Ruth Rubio-Marin and Martha I Morgan, in 'Constitutional Domestication of International Gender Norms: Categorisations, Illustrations and Reflections from the Nearside of the Bridge,' Karen Knopp (ed.) Gender and Human Rights (2004) Oxford University Press, Oxford,.113 suggest that the principal way that these three forms transmit international law is through transjudicialism.

47 Renata Uitz, Freedom of Religion in European Constitutional and International Law (2007) Council of Europe Publishing, Strasbourg.

${ }^{48}$ European Commission Against Racism and Intolerance (ECRI), ECRI General Policy

Recommendation No 5, On Combating Intolerance and Discrimination Against Muslims, Adopted $16^{\text {th }}$ March 2000, Strasbourg 2000.
} 
Under the European Convention on Human Rights and Fundamental Freedoms, the right to 'freedom of religion' and to 'manifest religion' appears as Article 9 (1) and (2) and corresponds closely to the wording of Article 18 of the International Covenant on Civil and Political Rights (ICCPR) and the 'right to religion' in the Universal Declaration on Human Rights (UDHR) Article 19. The Article asserts an absolute right to 'freedom of religion' under Article 9(1) and distinguishes a limited right to 'manifest religion' under Article 9 (2) which provides that it can be curtailed by:

"Such limitations as prescribed by law and are necessary in a democratic society in the interests of public safety, for the protection of public order, health or morals, or for the protection of the rights and freedoms of others. "49

Where a claim is brought in relation to rights that are 'limited' in this way, the ECtHR must first evaluate if there has been some interference with the right. It must then consider whether the interference was carried out in accordance with 'law' and whether it was in pursuance of a 'legitimate aim', and, finally, the Court must ask whether the interference was 'necessary in a democratic society,' taking into account whether the level of interference was proportionate in relation to the aim pursued. In relation to the latter, there is a 'margin of appreciation' allowed to each state within which the courts can consider the specific conditions pertaining to the state in question. This means making allowances for local conditions between states in the way that rights are implemented. When applying the 'margin of appreciation', the Court evaluates how other member states have dealt with the same rights within their domestic jurisdictions. In addition, there is often an attempt within Court decisions to locate the European position within wider rights jurisprudence.

The history of adjudication on Article 9 under the ECHR supports Paul Marshall's findings on the global neglect of the rights to religion. ${ }^{50}$ Though the Convention on Human Rights and Fundamental Freedoms came into being in $1953,{ }^{51}$ the first Article

\footnotetext{
${ }^{49}$ European Convention on Human Rights and Fundamental Freedoms Article 9, http://conventions.coe.int/Treaty/Commun/QueVoulezVous.asp?NT=005\&CL=ENG

50 See Marshall, above n 5...

51 It was opened for signature in 1950.
} 
9 claim under individual petition ${ }^{52}$ was not considered in the ECtHR until $1993 .^{53}$

Claims were made before this, but relying on the distinction between the right to 'freedom of religion' and the right to 'manifest religion' the European Commission on Human Rights deemed these inadmissible. Of those Article 9 cases found to be admissible, the Court has been heavily criticised ${ }^{54}$ for its differential handling of rights to religion and in particular for its construction of some religions as 'other' in the context of European experience. ${ }^{55}$ Even so, there appears to be especially poor treatment of claims to be free to manifest religion made by women. ${ }^{56}$ This can be located within a wider trend within ECHR jurisprudence to fail to develop equality jurisprudence under Article $14^{57}$ and to engage fully with women's rights. ${ }^{58}$

In the years before Sahin v Turkey, ${ }^{59}$ the seminal case in this area which I discuss below, a number of similar claims had been deemed inadmissible by the Commission. For instance the Commission had previously dismissed 'as manifestly unfounded' claims by a teacher who was prevented from wearing a headscarf in her employment (Dahlab v Switzerland) and a student who was unable to graduate unless she removed her headscarf for a photo (Karaduman v Turkey). ${ }^{60}$ Therefore, despite the poor history of adjudication on Article 9 claims there was great hope when $\operatorname{Sahin}^{61}$ was held to be admissible. In Turkey, there was a belief that this claim would be considered in the light of other Turkish rights breaches and hope that this jurisprudence would

\footnotetext{
52 It was optional for countries to allow this procedure until Protocol 11 in 1998.

53 Marie Benedict Dembour, 'The cases that were not to be: Religious Freedom and the European Court of Human Rights' in Italo Pardo, (ed.) Morals of Legitimacy: Between Agency and System(2000) Berghahn Books, Oxford, 208..

54 See for instance Clare Overy and Robin White, Jacobs and White: European Convention on Human Rights (2002), Oxford University Press, Oxford, and Dembour, ibid.

55 Dembour, above n.52.

56 See for instance Dahlab v Switzerland (Application 42393/98) Decision $15 \mathrm{feb}$ 2001http://www.law.yale.edu/documents/pdf/Intellectual_Life/Dahlab_v_Switzerland.pdf and Karaduman v Turkey (Application no. 16278/90) decision of 3 May 1993.

57 Overy and White, above n 53; Gay Moon, 'The Draft Discrimination Protocol To The European Convention on Human Rights: A Progress Report' (2000) 1 European Human Rights Law Review 49.

${ }^{58}$ Marie Benedict Dembour, Who Believes in Human Rights? The European Convention in Question (2006) CUP, Cambridge. In contrast to MC v Bulgaria (application no 39272/98) 2003 http://www.coe.int/t/e/legal_affairs/legal_cooperation/fight_against_sexual_exploitation_of_children/1_pces/CASE\%20OF\%20MC\%20v.\%20BULGARIA.pdf, provides an exemplary judgement. This difference in this case was that Interights, a rights NGO, provided a third party comments and drew the Courts' attention to how this case in point fitted into a wider equality framework. The Court was also invited to take note of international reports and recommendations on women's rights.

${ }^{59}$ Case of Leyla Sahin v Turkey Application 44774/98 Chamber judgment decision $8^{\text {th }}$ of June 2004 Grand Chamber Judgment $10^{\text {th }}$ of November 2005.

${ }^{60}$ See above n 55 .

61 Ibid.
} 
contribute to the development of a culture of respect for rights by the Turkish government. $^{62}$

The case of Leyla Sahin concerned a student who was excluded from her university for wearing a headscarf. Leyla Sahin, a practising Muslim, studied medicine in Turkey from 1993 until her expulsion from the University of Istanbul in 1998. She chose to manifest her religion by wearing a headscarf and had worn a headscarf to the University of Bursa for the four years she studied there. She was also initially allowed to wear it to the University of Istanbul when she transferred her studies there in 1997. In February 1998, the university issued a circular notifying that there would be a clamp down on prohibited forms of dress, which included the wearing of 'Islamic headscarfs'. In March 1998, Sahin was first refused access to her year five exams because she was wearing a headscarf. Subsequently she was refused access to other classes and exams. Although her actions remained peaceable and her protests consisted of appealling to the authorities, she refused to remove her headscarf and was expelled. After exhausting her claims in the domestic courts, she applied to the European Court of Human Rights. ${ }^{63}$ She argued that the ban and the expulsion had breached her Article 9 'right of freedom to manifest religion' and her Protocol 1 (2) right to 'freedom to education' she also claimed a breach of Article 8 right to private and family life, Article 10, right to freedom of expression and Article 14 the right to be free from discrimination, in relation to enjoyment of the Convention rights.

The case was first heard by a Chamber of 9 judges and then, on appeal by Sahin, to a Grand Chamber composed of 17 judges. The Grand Chamber affirmed the decision and reasoning of the Chamber in finding that there was interference with Article 9(2) but there was no breach of Article 9 and that Articles 8, Article 10, and Article 14 which were considered to have added nothing to the claim.

Unlike the Chamber, the Grand Chamber found it was appropriate to consider the Protocol 1 Art. 2 right to education separately. In relation to this they also found

\footnotetext{
${ }^{62}$ Nora Onar, 'Freedom of Religion vs. Secularism?: Universal Rights, Turkish Islamism, and the Headscarf' RAMSES Working Paper 8/07 April 07 European Studies Centre of Oxford. http://www.sant.ox.ac.uk/esc/ramses/onar.pdf

${ }^{63}$ By the time the ECtHR heard her case she had completed her medical education at a University in Vienna.
}

Public Space: The Journal of Law and Social Justice (2009) Vol 4, pp 34-73 
interference with the right, which had been restricted by the prohibition in the circular. ${ }^{64}$ In keeping with the finding on Article 9, they likewise considered that the aim of keeping educational institutions secular was a legitimate aim because it related to the protection of the rights and freedoms of others ${ }^{65}$ and that it had been imposed proportionally. ${ }^{66}$

The approach taken by both chambers was surprising. As noted by Judge Tulkens in her dissenting opinion, it seemed that the Court had abandoned its role of review altogether. ${ }^{67}$ Certainly the logic used to support Turkey's position was flawed and clearly based on a number of presumptions rather than any evidence presented by the state. Arguably, it seems that neo-orientalist perspectives blinded both Chambers from requiring the state to prove the case for interference. The Grand Chamber accepted without demur the assertion by Turkey that the interference was 'reasonably necessary in a democratic society' in order to pursue the legitimate aims of maintaining secularism and promoting women's equality. ${ }^{68}$ The problem, as pointed out by Judge Tulkens in her dissenting judgement, is that the claims of the state are not submitted to any rigorous human rights analysis. ${ }^{69}$ While Turkey raised women's equality as a 'legitimate aim', Turkey neither had to justify headscarf bans as necessary to achieve this aim nor argue that they were a proportionate way of achieving it. Moreover, the Grand Chamber accepted that equality for women could only be achieved within the particular brand of secularism espoused by Turkey without stating why it considered this to be so. The claims were seen as self-evident.

The key to this thinking lies perhaps in the unequivocal position that the Grand Chamber adopted in relation to the 'headscarf.' In a statement, cited with approval by both Chambers, from the earlier report on Dahlab v Switzerland ${ }^{70}$, the Commission referred to the headscarf as a 'powerful external symbol' capable of having a 'proselytising effect, seeing that it appeared to be imposed on women by a religious

\footnotetext{
${ }^{64}$ Sahin v Turkey above n 6 at paragraph 157.

${ }^{65}$ Ibid at 158.

66 Ibid at $159-162$.

${ }^{67}$ Ibid, dissenting Opinion of Judge Tulkens, para 3.

${ }^{68}$ Dahlab v Switzerland 42393/98 15 January 2001 http://www.law.yale.edu/documents/pdf/Intellectual_Life/Dahlab_v_Switzerland.pdf

${ }^{69}$ Sahin v Turkey above n 6 Dissenting Opinion of Judge Tulkens, para 3.

70 Dahlab v Switzerland 42393/98 15 January 2001
} 
precept that was hard to reconcile with the principle of gender equality. ${ }^{71}$ This, it was said by the Commission in Dahlab, 'could not easily be reconciled with the message of tolerance, respect for others and, above all equality and non-discrimination that all teachers in a democratic society should convey to their pupils. ${ }^{72}$ By supporting this view of the headscarf the Grand Chamber assigns the applicant to a dual role as a 'victim' who is forced to wear the headscarf by religious precept, and also as a member of an aggressor religion posing a threat to tolerance, democracy and to other women. ${ }^{73}$ Debate on the meaning of the headscarf is absent and the Grand Chamber seems to believe that it needs no more evidence of a threat to democracy or of the impact on women's equality. In this way, the Grand Chamber confuses two issues: Sahin's individual right to manifest personal religious beliefs by wearing a headscarf and the corporate right of a monolithic 'Islam' to impose the headscarf on women.

It is problematic that the Grand Chamber addresses this case as if it is about a ban on religious symbols in general ${ }^{74}$ when it is only limited to Islamic religious symbols. ${ }^{75}$ It is also problematic that there is no discussion of the nature of secularism and its relation to democracy. The assumption that the wearing of religious symbols in public institutions per se is both incompatible with secularism and a threat to secularism is not based on any evidence. ${ }^{76}$

Judge Tulkens makes the point very clearly that the judgment elides fundamentalism with headscarf wearing and shows why the Grand Chamber is not entitled to do this:

"While everyone agrees on the need to prevent radical Islamism, ... [m] erely wearing the headscarf cannot be associated with fundamentalism and it is vital to distinguish between those who wear the headscarf and 'extremists' who seek to impose the headscarf as they do other religious symbols. Not all women who wear the headscarf

\footnotetext{
71 Ibid.

72 Sahin v Turkey Grand Chamber, para 111. See also Tulkens dissenting judgment for comment on this, at para 12 .

73 Ibid. See the Commissions full statement in Dalhab v Switzerland 42393/98 15 January 2001at page 15.http://www.law.yale.edu/documents/pdf/Intellectual_Life/Dahlab_v_Switzerland.pdf

${ }^{74}$ Para. 116.

75 Para. 16.

76 Arguably the purpose of a secular state is to be impartial and ensure that all have equal freedom of thought and religion rather than to prevent the expression of religious belief. Moreover Freeman questions the very notion of human rights as secular see Michael Freeman, ' The Problem of Secularism in Human Rights Theory'(2004) 26 Human Rights Quarterly 375.
}

Public Space: The Journal of Law and Social Justice (2009) Vol 4, pp 34-73 
are fundamentalists and there is nothing to suggest that the applicant held fundamentalist views... The applicant's personal interest in exercising the right of freedom of religion and to manifest her religion by an external symbol cannot be wholly absorbed by the public interest in fighting extremism. ${ }^{77}$

Equality and non-discrimination are subjective rights which must remain under the control of those who are entitled to benefit from them. 'Paternalism' of this sort runs counter to the case-law of the Court, which has developed a real right to personal autonomy on the basis of Article 8..."78

Tulkens contrasts the position of Leyla Sahin with the male applicant in Gundez v Turkey. In Gundez once again the ECtHR expressed neo-orientalist views, presenting Islam as a monolithic and anti-democratic entity. Despite this, they were still concerned to recognise the balance between fighting extremism and individual freedom:

"It [is] difficult to declare ones support for democracy and human rights while at the same time supporting a regime based on Sharia... Sharia which faithfully reflected the dogmas and divine rules laid down by religion, was stable and invariable and clearly diverged from Convention values, particularly with regard to its criminal law and criminal procedure, its rules on the legal status of women and the way it intervened in all spheres of private and public life in accordance with religious precepts.... However the Court considers that the mere fact of defending Sharia without calling for violence to establish it cannot be regarded as 'hate speech'," 79

One difference in this case is that the Chamber considered it was dealing with 'speech' which they regarded as political expression. In Sahin the Grand Chamber accepted the government's view of the headscarf as a political symbol but they would not recognise Sahin's claim to freedom of expression. This position is contradictory: though Sahin was not wearing the headscarf as a political statement Turkey had

\footnotetext{
77 Sahin, Grand Chamber Judgement, above n 6. Judge Tulkens dissent, para 10.

${ }^{78}$ Ibid., Judge Tulkens dissent, para 12.

${ }^{79}$ Gundez v Turkey (Application no. 3507/97) 4 December 2003 http:/cmiskp.echr.coe.int/tkp197/viewhbkm.aspsessionID $=15331725$ ?

Para 52.
}

Public Space: The Journal of Law and Social Justice (2009) Vol 4, pp 34-73 
politicised headscarf-wearing, so her opposition to the ban is clearly political expression. In this sense, the positions adopted by the ECtHR in Sahin and Gundez seem irreconcilable and reveal a clearly gendered difference in approach to the two cases. 'Thus, manifesting one's religion by peacefully wearing a headscarf may be prohibited whereas, in the same context, remarks which could be construed as incitement to religious hatred are covered by freedom of expression. ${ }^{, 80}$

The language and logic behind the Grand Chamber's neo-orientalist approach suggests the continuation of a tradition of older discourses. In particular, writers discussing orientalism note the "enduring fascination with the harem and the veil. ${ }^{, 81}$ Current discourses around the headscarf are still heavily influenced by 19th Century interpretations which viewed 'veiling' as the visible signifier of the oppression of Muslim women. ${ }^{82}$ Joan Scott Wallach suggests that it is significant that the term 'veil' is still widely used to refer to all forms of 'hijab' - including headscarves - which do not cover the face, and argues that this indicates deep anxieties about the identification of Islam and women. ${ }^{83}$

This neo-orientalist position taken by the Commission and the ECtHR on headscarves is echoed by other Council of Europe institutions. Shortly before the decision from the Grand Chamber, the Council of Europe Parliamentary Assembly debated a report, produced by the Committee on Equal Opportunities for Women and Men, on Women and Religion in Europe ${ }^{84}$ and subsequently passed a resolution of the same name. ${ }^{85}$ The report was striking in that it presented a partial look at the problems associated with women and religion in Europe. It focussed only on the problems posed to women from within their religious communities rather than also looking at the discrimination experienced by women on the basis of their religion. In the report, the Special

\footnotetext{
${ }^{80}$ Sahin, above n 6 Tulkens, para. 9.

${ }^{81}$ Weber, above n 28, 125.

82 Ibid.

83 Joan Scott Wallach, The Politics of the Veil ( 2007) Princeton University Press, Princeton.16, and see Chapter 5. In response to this focus and fixation with the 'veil' some young women have adopted the headscarf as a political statement against the oppression of their communities. See Joseph Carens, Culture, Citizenship and Community: A Contextual Exploration of Justice as Even-handedness (2000) Oxford University Press, Oxford 160-161.

${ }^{84}$ Rosemarie Zapfl-Helbling Women and Religion in Europe Doc. $1067016^{\text {th }}$ September 2005. http://assembly.coe.int/Documents/WorkingDocs/doc05/EDOC10670.htm

${ }_{85}$ Parliamentary Assembly Resolution 1464, Women and Religion In Europe, (2005) $4^{\text {th }}$ October 2005.
} 
Rapporteur ${ }^{86}$ acknowledges that there are criticisms of the way that all religions treat women but, despite this, her focus is clearly on the threats that she perceives as coming from outside Europe. For instance, she cites 'female genital mutilation, crimes of honour, certain practices linked to marriage and its dissolution, lack of access to education or certain professions, and the preference for boys' as obvious examples of '...ostensibly religious practices violating women's rights ${ }^{, 87}$ and she notes that these are associated with "certain minority religions or immigrant communities. ${ }^{, 88}$ This is despite the fact that these 'ostensibly religious practices' have no ostensible links with religion.

The report also asserted that the 'most widespread and visible problem in Europe concerns the Islamic dress code for women, i.e. the headscarf. ${ }^{, 89}$ While the Rapporteur recognises that there is some debate on symbolic significance, she believes that '.. it is often impossible to determine whether the wearing of a headscarf (or more covering garments) is imposed, self imposed or a matter of free choice..., 90 However, any nuance in the debate on meaning disappears with the Rapporteur's statement that:

'[T] he reason why I find it so difficult to respect the headscarf as a religious symbol like any other is that there is so much baggage that comes with it, a sense of submission to the control by men of a girl or woman's destiny and the way she leads her life. Allowing young girls to wear headscarves in school can quickly lead to other demands by certain Muslim communities, such as separate swimming or sports lessons for girls in schools, or even the banning of co-education altogether. Where do we draw the line?" 91

\footnotetext{
${ }^{86}$ Rosmarie Zapfl-Helbling, President of the centre-right Christian Democratic Party.

87 Para 10.

88 Ibid.

89 Para 20.

${ }^{90}$ Para 20.

${ }_{91}$ Para 23. These examples seem strange since separate games lessons and single sex schooling are hardly alien institutions in Europe. The implication though seems to be $t$ to link the headscarf ultimately to the 'harms' presented in the earlier paragraph.
}

Public Space: The Journal of Law and Social Justice (2009) Vol 4, pp 34-73 
In the final Resolution passed by the Parliamentary Assembly, religious dress codes are censured $^{92}$ and this provides a tacit approval of the decision in Sahin.

\section{IV - The Human Rights Context And Consequences Of This Approach}

In coming to their decision in the Sahin case, the Grand Chamber looked at the situation in other countries within the Council of Europe and also referred to Council of Europe materials on higher education. ${ }^{93}$ The Judges noted that some other countries had headscarf bans within schools and public institutions but there seemed to be no consensus among member states on whether this was appropriate. This lack of consensus was used to justify the wide margin of appreciation allowed to Turkey by the Grand Chamber. However, as Judge Tulkens points out, at this time no other state in the Council of Europe had a ban on the headscarf for adult students. ${ }^{94}$ Furthermore, in Sahin, Council of Europe recommendations on the role of higher education in promoting human rights and tolerance ${ }^{95}$ were in effect used contrary to their intention $^{96}$ as justification for excluding religious attire. ${ }^{97}$

It is notable that in Sahin, the Grand Chamber did not refer to the European Commission Against Racism and Intolerance (ECRI) Policy Recommendation 5 issued in 2000. This recommendation was entitled Combating Intolerance and Discrimination against Muslims. It recognised the prevalence of orientalist discourse and 'strongly regretted that Islam is sometimes portrayed inaccurately on the basis of

\footnotetext{
92 Parliamentary Assembly Resolution 1464, Women and Religion in Europe, 2005, $4^{\text {th }}$ October 2005, para.7.4.

93 Sahin v Turkey above note 6. Para 55- 69.

94 Ibid. Tulkens' dissenting Judgment Para 7.

95 Ibid 66-69.

96 See full text of Council of Europe Recommendation on Access to Higher Education R (98) 3 at https://wcd.coe.int/com.instranet.InstraServlet?command=com.instranet.CmdBlobGet\&InstranetImage $=530617 \&$ SecMode $=1 \&$ DocId $=459344 \&$ Usage $=2$ at November 2008 and Recommendation 1353 (1998) Access of Minorities to Higher Education at http://assembly.coe.int/Main.asp?link=/Documents/AdoptedText/ta98/EREC1353.htm at November 2008

97 Sahin v Turkey, above n 6 at 116.
}

Public Space: The Journal of Law and Social Justice (2009) Vol 4, pp 34-73 
hostile stereotyping... ${ }^{98}$ The committee said it was 'rejecting all deterministic views of Islam and recognising the great diversity intrinsic in the practice of this religion.' Amongst other matters, the recommendation urged member states to 'take the necessary measures to eliminate any manifestation of discrimination on grounds of religious belief in access to education' 99 and advised member states to 'pay particular attention to the situation of Muslim women, who may suffer both from discrimination against women in general and from discrimination against Muslims... ${ }^{100}$ However, even if the Grand Chamber in Sahin had examined this recommendation, the specific points in it were aimed at 'governments of member states, where Muslim communities are settled and live in minority situation in their countries, ${ }^{101}$ so, by default, the ECRI excluded Turkey where Muslims are a majority.

In Sahin, no other international rights instruments or recommendations from regional or international Committees were examined, though at the relevant time, similar issues were being addressed by other international committees and non-governmental organisations. It is suggested that if the Grand Chamber had examined the issue within a wider frame, it may have had cause to re-think the simplicity of its conclusion about an automatic connection between the promotion of equality and human rights and the headscarf ban.

Given the emphasis placed on imposing the ban as part of a strategy to achieve women's equality, the Court should have gone on to consider whether this ban had any other consequences for women as well as how it fitted in with Turkey's wider equality strategy. The United Nations expert committee on women's rights, the Committee for the Convention on the Elimination of all forms of Discrimination against Women (CEDAW), considered Turkey's combined fourth and fifth reports in February 2005. This consideration took place after the Chamber decision but before consideration by the Grand Chamber. The CEDAW committee questioned statesanctioned activities which directly discriminated against and degraded women,

\footnotetext{
98 European Commission against Racism and Intolerance Policy (ECRi) General Policy Recommendation No. 5 Adopted $16^{\text {th }}$ March 2000, titled Combating Intolerance and Discrimination against Muslims. (2000) Council of Europe Strasbourg 3.

${ }^{99}$ Ibid 4, point 6; see also point 11.

100 Ibid 4, point 10.

101 Ibid 4.
} 
including so-called virginity checks on women. ${ }^{102}$ In the context of Turkey's failure to address its own obviously discriminatory policies and practices, its claims that the headscarf ban was motivated by equality concerns are dubious.

While the CEDAW committee did not specifically denounce the headscarf ban as contrary to women's rights, they raised concerns about its impact. The Committee was particularly concerned that, in Turkey, 'girls and women lag behind men and boys' in education and that female students tend to be 'directed into single sex vocational and technical high schools. ${ }^{103}$ In question and answer sessions, the Committee asked Turkey what measures it had taken to ensure that the headscarf ban did not affect the rights of women and girls to educational opportunities. ${ }^{104}$ No satisfactory answer was forthcoming and, in their concluding comments on the reports, they noted their concern in relation to the '...impact on girls and women of the ban on wearing headscarves in schools and Universities.' They asked specifically that Turkey '... monitor and assess the impact of the ban on wearing headscarves and [to] compile information on the number of women who have been excluded from schools and universities because of the ban., ${ }^{105}$

Also at this time, Human Rights Watch (HRW), a major international nongovernmental organisation, prepared a full briefing paper on the issue of the Turkish headscarf ban and its impact on academic freedom and women's access to higher education in Turkey. ${ }^{106}$ HRW not only considered the ban contrary to the right to manifest religion and contrary to equality principles, but also found serious harm to the education of girls and women as a consequence.

\footnotetext{
102 http://www.un.org/womenwatch/daw/cedaw/cedaw32/conclude-comments/Turkey/CEDAW-CCTUR-0523813E.pdf at November 2008

${ }^{103}$ Para 24 and 25 respectively CEDAW/PSWG/2005/I/CRP:1/add.8 pre-session working group for the 32 session 10-28 January.

104 Ibíd, para 26.

105 http://www.un.org/womenwatch/daw/cedaw/cedaw32/conclude-comments/Turkey/CEDAW-CCTUR-0523813E.pdf_para. 34 at November 2008. Earlier reports also highlighted state legal provisions which were directly discriminatory against women. In view of this the ECtHR might have least have queried the motivations of the Turkish state. See Consideration of the Turkish Combined Second and Third Reports By The Committee On The Elimination of Discrimination Against Women., 23/1/97.A/52/38/Rev.1.

${ }^{106}$ Human Rights Watch, Memorandum to the Turkish Government on Human Rights Watch's Concerns with Regard to Academic Freedom in Higher Education, and Access to Higher Education for Women who Wear the Headscarf (Human Rights Watch Briefing Paper June 29, 2004) http://www.hrw.org/legacy/backgrounder/eca/turkey/2004/index.htm
}

Public Space: The Journal of Law and Social Justice (2009) Vol 4, pp 34-73 
Prior to the Grand Chamber hearing, a case similar to Sahin was heard by the Human Rights Committee under the optional protocol to the ICCPR. In Raihon Hudoyberganova v Uzbekistan, ${ }^{107}$ a student claimed that an Uzbeki law prohibiting religious dress in public places had excluded her from a state university. She had been wearing 'hijab'. ${ }^{108}$ Her claim was brought under Freedom to Manifest Religion, Article 18 of the Covenant. The Committee was clear that the ban constituted interference with her right, and that the burden of proof lay with the State to justify this interference under the limitations allowed by Article 18. In stark contrast to Sahin v Turkey, the Committee upheld Hudoyberganova's complaint on the basis that it was not presented with evidence justifying the interference.

The worrying consequences of the Council of Europe's approach are three-fold. Firstly, it called the Council of Europe rights system into question. Secondly, it has been influential in changing the law of member states. Thirdly, and finally, this approach has supported damaging discourses around Islamic rights and particularly in relation to the rights of visibly Muslim women.

Following the decision by the Grand Chamber in Sahin, the Turkish 'Virtue Party' which had been dissolved by Turkey in 2001, withdrew its appeal to the ECtHR. ${ }^{109}$ The case had been pending since 2001. Nicholas Gibson notes that the reason given for the withdrawal was that the Party did not think it would get a fair hearing since the ECtHR had adopted a double standard when dealing with 'European Muslims [who are] confronted by injustice because of their beliefs. ${ }^{110}$ As Gibson suggests, whether or not you believe it to be true, this 'perception' is problematic in ensuring respect for the rule of law. ${ }^{111}$

\footnotetext{
107 Views of the Human Rights Committee Under the Optional Protocol to the International Covenant on Civil and Political Rights Eighty Second Session Communication No. 931/2000 CCPR/C/82/D/931/2000 8 December 2004 at http://www1.umn.edu/humanrts/undocs/html/9312000.html

108 The precise facts are not clear from a reading of the case and the Committee recognised that it had little information.

${ }^{109}$ COE Press Release Issued by the Registrar: Chamber Judgements Concerning Greece, Italy, Russia, Slovenia, and Turkey 245, 27.4.2006. http://www.echr.coe.int/Eng/Press/2006/April/Chamberjudgments270406.htm, 3 at 13 November 2008.

${ }_{110}$ Para 9 of App No. 1444/02 only available in French cited by Nicholas Gibson, 'Faith in the Courts: Religious Dress and Human Rights,' (2007)66 (3), Cambridge Law Journal 657 at 696.

${ }_{111}$ Ibid.
} 
The approach of the ECtHR appears to be at variance to those of other international rights bodies and there are concerns about its approach within the Council of Europe. In a number of reports submitted by the UN Special Rapporteur on Freedom of Religion and Belief in 2005 and 2006, concerns were raised about the ban on religious symbols, including headscarves. ${ }^{112}$ Judge Tulkens' dissent in the Sahin case was highlighted approvingly. ${ }^{113}$ A number of human rights non-governmental organisations - Amnesty International (AI), ${ }^{114}$ Human Rights Watch (HRW), ${ }^{115}$ International Helsinki Federation for Human Rights (IHF), ${ }^{116}$ and Office for Democratic Institutions and Human Rights (ODIHR) ${ }^{117}$ among them - have expressed the opinion that such bans are contrary to the human rights of women. ECtHR jurisprudence in relation to Islam and freedom of religion has been found to be problematic in a major report in the Council of Europe series, Europeans and Their Rights. ${ }^{118}$ If another case arises in the ECtHR it is to be hoped that the nongovernmental organisation, Interights, will intervene to ensure fair debate and adjudication. ${ }^{119}$ In the light of these concerns about the compatibility of bans on religious symbols with human rights norms, it is worrying that even if the case law from the ECtHR and the former Commission has not directly encouraged further bans on religious symbols, it has not checked it in any way. The link between earlier Commission and ECtHR cases and Turkey's move to renew the prohibition on headscarves is clear. The Circular which renewed the prohibition and led to Sahin's

\footnotetext{
${ }^{112}$ Asma Jahangir, (Special Rapporteur on Freedom of Religion or Belief) Civil and Political Rights, Including the Question of Religious Intolerance, Economic and Social Council E/CN.4/2005/61 20 December 2004; Jahangir, Asma, (Special Rapporteur on Freedom of Religion or Belief) Civil and Political Rights, Including the Question of Religious Intolerance: E/CN.4/2006/5 9 January 2006; Jahangir, Asma, (Special Rapporteur on Freedom of Religion or Belief) Implementation of General Assembly Resolution 60/251 of 15 th March 2006 Entitled 'Human Rights Council' A/HRC/4/21 26 December 2006.

113 Jahangir, Asma, (Special Rapporteur on Freedom of Religion or Belief) Civil and Political Rights, Including the Question of Religious Intolerance: E/CN.4/2006/5 9 January 2006, paras. 47 and 60.

${ }^{114}$ Amnesty International Report, The State Of the Worlds Human Rights (2007) http://archive.amnesty.org/report2007/document/231/default.htm at November 2008

${ }_{115}$ Human Rights Watch, above n 103.

116 International Helsinki Federation, Human Rights in the OSCE Region: The Balkans, the Caucasus, Europe, Central Asia and North American Report 2001 (Events 2000) http://www.ihfhr.org/documents/doc_summary.php?sec_id=3\&d_id=1783 at November 2008

117 Hate Crimes In the OSCE Region - Incidents and Responses Annual Report for 2007, Warsaw, October 2008 http://www.osce.org/publications/odihr/2008/10/33850_1196_en.pdf

118 Uitz, above $\mathrm{n} 50$.

119 Note than in the recent case of Opuz v Turkey App 33401/02 $9^{\text {th }}$ June 2009 Interights intervened and the result was a landmark ruling on the s duty of the state to protect women's rights in the context of domestic violence. The state was found to be at fault and the Court did not, as in Sahin, cite the Turkish constitution's respect for equality as a way of defeating the claim against the state. http://www.coe.int/t/dghl/standardsetting/violence/Opuz v Turkey.pdf at June 2009.
}

Public Space: The Journal of Law and Social Justice (2009) Vol 4, pp 34-73 
expulsion explicitly stated that it was regulating students' clothing 'by virtue of the Constitution, the law and regulations, and in accordance with the case-law of the Supreme Administrative Court and the European Commission of Human Rights..., ${ }^{120}$

Other Council of Europe members have also sought bans on religious dress in the context of state employment and educational institutions though no other country as yet has tried to limit the dress of university students. The ban on religious symbols in schools in France was introduced in 2004. ${ }^{121}$ Announced in early 2004, it came into force after the first Sahin decision. France has since gone further and refused a woman citizenship because she wore a niqab. ${ }^{122}$ Faiza Silmi, whose husband was already a citizen, had her application turned down on the basis of 'insufficient assimilation into France'. ${ }^{123}$ On appeal, the French Council of State said that she had 'adopted a radical practice of her religion, incompatible with essential values of the French community, particularly the principle of equality of the sexes... ${ }^{124}$ In Germany, over half of the sixteen Land (federal states) have enacted legislation to prohibit the wearing of headscarves by teachers and, in some cases, civil servants and law enforcement officers. ${ }^{125}$ The federal Constitutional Court in Germany overturned a prohibition imposed on a teacher by Baden-Württemberg in 2003 because there was no relevant legislation in place, but the decision left the way open for individual states to pass specific legislation. In some Land, the bans operate like the French ban against all conspicuous symbols; however, in five Land, the relevant legislation contains exemptions for Christian symbols such as nun's habits. ${ }^{126}$ These exemptions for Christian symbols have been justified on the basis that 'such clothing and symbols are

\footnotetext{
${ }^{120}$ Sahin (2004), above n 62 at para. 12.

121 The French ban differs from the Turkish in that it does not directly discriminate against Muslims because it covers all obvious religious symbols, not just Islamic symbols. The ban does not extend to Universities. However this is still of concern to the IHF and HRW who believe it contravenes human rights norms by indirectly discriminating against Muslims and by infringing the religious freedom and freedom of expression of other groups. IHF Press Release, 17 December 2004 'A French Ban on Religious Symbols Would Violate International Protection of Freedom of Religion.' Http//www.ihfhr.org. ; HRW France: Headscarf Ban Violates Religious Freedom 26 February 2004 http://www.hrw.org/en/news/2004/02/26/france-headscarf-ban-violates-religious-freedom

${ }_{122}$ This is a something which is worn to cover the nose and mouth but leaves the eyes visible.

${ }^{123}$ Katrin Bennhold, 'A Veil Closes France's Door to Citizenship.' The New York Times, 19 July 2008, 1.

124 Ibid 2.

125 Human Rights Watch, Discrimination in the Name of Neutrality: Headscarf Bans for Teachers and Civil Servants in Germany, 1-56432-441- 9 February 2009 http://www.hrw.org/Discrimination in the Name of Neutrality I Human Rights Watchen/node/80829/section/4 at March 2009.

126 Ibid 26.
} 
in line with and preserve the values in their state constitutions (themselves influenced by Christianity) ... government entities have claimed that Christian clothing and symbols do not therefore risk compromising the neutrality or peace of the school. ${ }^{, 127}$ The headscarf, they say, is a "political symbol of Islamic fundamentalism, which expresses the dissociation from values of the Western society like individual selfdeterminism and emancipation of women. ${ }^{128}$

These examples from France and Germany are not isolated, several other countries in the Council of Europe have also instated headscarf bans and, in January of 2008, there was an attempt to get the EU to commit to a legislative ban across all member states in relation to 'headscarves and hijab at least at primary school..., ${ }^{129}$ This was defeated by 367 to 200 votes (134 abstentions). ${ }^{130}$ Although the UK does not have any legislative prohibitions in place, the influence of ECtHR jurisprudence became evident in a recent case concerning a Muslim girl, Ms Begum, who took her school to court because it would not let her wear the jilbab, a long, long sleeved coat. ${ }^{131}$ The Court of Appeal found that the school had not adopted the right tests and, in particular, had not considered whether there was sufficient justification for preventing Ms. Begum's choice of clothes. For this reason, they found in Begum's favour, although they also noted that their holding did not preclude a correctly-reached decision to prohibit this clothing. In contrast, the House of Lords was unanimous in finding in the school's favour although different approaches were adopted by the Law Lords in coming to this conclusion. Two of the members, Lady Brenda Hale and Lord Nicholls, were concerned that the school be found to justify their decision, and held,

\footnotetext{
127 Ibid 27.

128 Ibid 29. citing the debate in North Rhine-Westphalia Parliament (emphasis added).

129 European Parliament, Report: Towards an EU Strategy on the Rights of the Child, Committee on Civil Liberties, Justice and Home Affairs. (Draftswoman Marie Panaytopolos-Cassiodorus, Committee on Women's rights and Gender Equality. A6-0520/2007, RR\39081EN.doc PE390.381v03-00 20.12.2007. Para 127.

${ }^{130}$ This particular proposal was defeated on 16 January 2008.

http://www.euronews.net/2008/01/16/meps-reject-muslim-headscarf-ban-in-primary-schools/. Figures for the vote are taken from Scottish MEP Alyn Smith's website.

http://www.alynsmith.eu/news/128/64/SNP-MEP-And-MSP-Team-Hail-Rejection-Of-Call-For-EUHeadscarf-Ban.html. For the debate see http://www.europarl.europa.eu/sides/getDoc.do?type=REPORT\&reference=A6-2009$0012 \&$ format $=X M L \&$ language $=E N$ at May 2009

${ }^{131} \mathrm{R}$ (on the application of Begum ( by her litigation next friend, Rahman)) (Respondent) v. Headteacher and Governors of Denbigh High School (Appellants) [2006] UKHL 15 http://www.publications.parliament.uk/pa/ld200506/ldjudgmt/jd060322/begum.pdf at November 2008
}

Public Space: The Journal of Law and Social Justice (2009) Vol 4, pp 34-73 
on all the evidence, that they had done so. ${ }^{132}$ Lady Hale discussed Judge Tulkens dissent in Sahin with approval and distanced her opinion from the majority decision in Sahin, noting that, in this case, there was 'the evidence ...., which Judge Tulkens found lacking in the Sahin case... ${ }^{133}$ The other three Lords made reference to Sahin and on the basis of their understanding of the discussion of a right to education, held that it was not necessary for the school to show any justification for their actions. Begum, they argued, had not had her right interfered with because she could leave that particular school and go to school elsewhere. ${ }^{134}$

At present, the Council of Europe seems to be at variance with other rights agencies, yet Sahin holds some authority, even outside the jurisdiction of the Council of Europe. For instance, in the Human Rights Committee ICCPR case of Raihon Hudoyberganova v Uzbekistan, ${ }^{135}$ Ruth Wedgwood, a member of the US Secretary of State Advisory Committee on International Law, the US National Security Group and US expert at the UN Human Rights Committee, cited Sahin v Turkey with approval in her individual (dissenting) opinion in the case. ${ }^{136}$ It is also unclear exactly how the Committee on the Elimination of Discrimination against Women (CEDAW) regards this issue. Rahime Kayan v Turkey, a claim brought by a Turkish teacher who was sacked for wearing a headscarf, was dismissed because the Committee considered that the applicant had failed to exhaust her domestic remedies. ${ }^{137}$ Though the Committee continues to raise concerns around state bans on religious clothing in its reports, it has yet to refute arguments that the bans are legitimately driven by concern for equality. $^{138}$

\footnotetext{
132 Ibid at 41.

133 Ibid at 98.

134 For the UK, this marks a retrograde step in the understanding of discrimination, as compared to the approach in Mandla v Dowell Lee [1983] 2 AC 548 (UK House of Lords), a case heard under the Race Relations Act in the early 1980's.

${ }^{135}$ Communication No. 931/2000 UN Doc. CCPR/C/82/D/931/2000 (2004). http://www1.umn.edu/humanrts/undocs/html/931-2000.html at March 2009.

136 This dissent appears in the report of the case above but has disappeared from others.

137 Rahime Kayhan v Turkey Communication No-8/2005 CEDAW/c/34/D/8/2005.

138 See for instance The 2008 Annual Report of the Committee on the Elimination of Discrimination against Women 40th and $41^{\text {st }}$ session, UN, New York 2008, http://daccessdds.un.org/doc/UNDOC/GEN/N08/458/40/PDF/N0845840.pdf?OpenElement at March 2009, paras. 324 and 325 - comments on French submission. In contrast see shadow reports to the Committee - which believe the bans to be a clear breach of CEDAW. For instance the Dutch Equal Treatment Committee Commissie Gelijke Behandeling 2009 http://www2.ohchr.org/english/bodies/cedaw/docs/ngos/CGB_Netherlands_cedaw45.pdf at March 2009.
} 
In addition to its influence on rights discourse and adjudication, the message conveyed by the determinations of the former Commission and the ECtHR has wider consequences. The support for state headscarf bans also has dire consequences for the everyday lived experience of Muslim women and particularly 'visible' Muslim women in Europe. Until recently, very few countries recorded incidents of hate crime against Muslims, ${ }^{139}$ although the ECRI recommended that all countries do this. ${ }^{140}$ Where reporting is taking place, the European Union Monitoring Centre notes increases in discrimination and abuse against Muslims and they estimate that the problem is far greater than conveyed by existing statistics. ${ }^{141}$ Women wearing headscarves are visible representatives of an Islamic religion and culture which has become stigmatised as 'other' in Europe. After the London bombings of 2005, the Chair of the Council of Mosques in the UK noted the increasing number of verbal and physical attacks on Muslim women wearing the headscarf and advised women to protect themselves by abandoning the headscarf if they felt threatened. ${ }^{142}$ Attacks on women wearing the headscarf are Europe-wide. The European Union Agency for Fundamental Rights (FRA) report from 2006 noted increasing numbers of attacks across Europe on women wearing headscarves. ${ }^{143}$ The ODIHR report on Hate Crimes in the OSCE Region similarly noted that women wearing the headscarf were being targeted. ${ }^{144}$ The reports also note that attackers often remove or try to rip off the headscarves.

\footnotetext{
139 Though the discrimination has been evident.

140 European Commission Against Racism and Intolerance (ECRI), ECRI General Policy

Recommendation No 5, On Combating Intolerance and Discrimination Against Muslims, Adopted $16^{\text {th }}$ March 2000. Strasbourg 2000.

http://www.coe.int/t/dghl/monitoring/ecri/activities/gpr/en/recommendation_n5/Rec5 en21.pdf at March 2009.

${ }^{141}$ See for instance the report from the European Union Monitoring Centre ' Racism and Islamaphobia in the Member States of the EU' December 2006 http://fra.europa.eu/fra/material/pub/racism/reportracism-0807-en-pdf at 1 December_2007.

${ }^{142}$ Reported on BBC News Tuesday $4^{\text {th }}$ of August 2005 http://news.bbc.co.uk/1/hi/uk/4742869.stm. at November 2008.

${ }^{143}$ European Union Monitoring Centre 'Racism and Islamaphobia in the Member States of the EU' December 2006 http://fra.europa.eu/fra/material/pub/racism/report-racism-0807-en-pdf at December 2007.

${ }^{144}$ OSCE Office For Democratic Institutions and Human Rights - Hate Crimes in the OSCE RegionIncidents and Responses, Annual Report for 2007, Warsaw October 2008 http://www.osce.org/odihr/item_11_33850.html at November 2008.
}

Public Space: The Journal of Law and Social Justice (2009) Vol 4, pp 34-73 
These statistics might be interpreted to suggest that the headscarf acts merely as an identifier of a stigmatised community, but a number of authors/activist groups posit a stronger connection between the nature of the debate around the headscarf and attacks on Muslims, particularly Muslim women. The International Helsinki Federation suggested that 'laws targeting' the 'Islamic headscarf' serve 'to mistakenly stigmatise all Muslim women wearing the headscarf as religious fundamentalists. ${ }^{145}$ The ODIHR notes that when bans are proposed on headscarves the discourse focuses on the headscarf as both a symbol of oppression and as symbolic of 'a lack of willingness to integrate into host societies. ${ }^{146}$ It argues that attacks on women wearing headscarves must be viewed within the context of this public discourse. So, while I do not suggest that debate itself focuses attention on the headscarf as a locus for hatred against Islamic communities, I believe that the reductive nature of these debates leads to the headscarf as a source of stigmatism.

The problem of feminist engagement with this area becomes apparent when attacks on Muslim women by either the state or dominant majority groups are ignored by feminist analysis. When some feminist groups praise the outcome of Sahin and themselves view women wearing the headscarf either as 'victims' or as traitors to a feminist cause, ${ }^{147}$ it seems that a concern for women's rights has been abandoned in favour of a logic of assimilation.

\section{Conclusion}

This article examined the interrelationship between feminism and 'orientalism' in relation to approaches taken by the Council of Europe in relation to women's right to religion. The European Court of Human Rights and the Commission before it and the Committee on Equality fail to see Muslim women as full rights-holders in relation to the right to religion because they hold a vision of an 'equal woman' as a woman who

\footnotetext{
145 Speaking of France in 2005 'A French Ban on Religious Symbols Would Violate International Protection of Freedom of Religion.' Http//www.ihf-hr.org. at 1 December 2007.

146 OSCE, Hate Crimes in the OSCE Region, above n 144 at 90 footnote 445.

147 See Women Living Under Muslim Laws' interview of 'Four Francophone Feminists on the 'headscarf ban', http://www.wluml.org/english/newsfulltxt.shtml?cmd[157]=x-157-44910 at May 2009.

See also the response from some English 'feminists' to Manal Omar's article 'I Felt More Welcome in the Bible belt' Guardian Friday April 2007 http://www.guardian.co.uk/lifeandstyle/2007/apr/20/fashion.religion at November 2008.
}

Public Space: The Journal of Law and Social Justice (2009) Vol 4, pp 34-73 
is free from religious identity. This position is supported by essentialist feminist perspectives which fail to recognise both the intersectional nature of identity and understand the way in which this mediates discrimination against women. The persistence of this 'orientalist' perspective from the European Convention treaty bodies simultaneously causes and obscures the very serious discrimination facing women from minority groups in Europe. It does both of these things by effectively sanctioning breaches of the right for Muslim women to manifest religion and contributing to a negative discourse which makes Muslim women targets for hate crimes.

It is indeed ironic that women are treated less favourably through a rhetoric of equality and 'women's rights' and it raises serious questions about the universality in the application of rights to Muslim women. There is a need to rethink frameworks which regard 'equality' as antithetical to 'culture' and incompatible with non-Western contexts. This is not to abandon a universal application of human rights: rather it is to 'respond to the debate by emphasising that all women have a universal right to the enjoyment of all human rights, although all women's experiences, strategies and choices in affirming those rights need not be identical. ${ }^{148}$

Irene Khan, Secretary General of Amnesty International, argues that the most powerful tool against gender violence, intolerance, racism, xenophobia and terrorism is the universality of rights applied equally to men and women 'universal in both understanding and application. ${ }^{149}$ Ms Khan argues that:

“The state has the obligation to safeguard a woman's freedom of choice not restrict it. ... It is wrong for women in Saudi Arabia or Iran to be compelled to put on the veil. It is equally wrong for women or girls in Turkey or France to be forbidden by law to wear the headscarf. ... In the exercise of her right to freedom of expression and religion, a woman should be free to choose what to wear."

\footnotetext{
148 Kerr, above n. 12, 30 citing Charlotte Bunch.

149 Irene Khan, 'Foreword to 2007 Amnesty International Annual Report' Amnesty International Report 2007: The State of the Worlds Human Rights, http://archive.amnesty.org/report2007/document/231/default.htm_, 8. At 20 October 2008.
}

Public Space: The Journal of Law and Social Justice (2009) Vol 4, pp 34-73 
In looking to use global systems and the benefits of mass communication and organisation to advance women's rights, advocates need to take care to listen to the people whose rights they wish to support. The urge to a supposed universality which in fact obscures a 'logic of assimilation' and supports neo-imperialist globalising forces must be resisted. In 1984, Chandra Mohanty stated that 'One such significant effect of the dominant 'representations' of Western feminism is its conflation with imperialism .... Hence the urgent need to examine the political implications of analytic strategies and principles. ${ }^{150}$ This imperative is arguably even more urgent in the current climate. 'Orientalist' perspectives are undoubtedly present in all areas of international law ${ }^{151}$ and jurisprudence on freedom of religion pays insufficient attention to them ${ }^{152}$ While this article has focussed on the gendered problem of an orientalist perspective for women's rights, it also raises wider concerns in relation to the right to be 'other' in Europe.

150 Mohanty, above n 25, 336.

151 Youmans, above n 28; Allain, above n 28; Falk, above n 17.

${ }^{152}$ Marshall, above n 5. 


\section{Bibliography}

\section{Articles/Books/Reports}

Akram, S. M, 'Orientalism Revisited in Asylum and Refugee Claims' International Journal of Refugee Law, (2000) 12:1 7-40.

Allain, J, 'Orientalism and International Law: The Middle East as the Underclass of the international Order' Leiden Journal Of International Law (2004) 17 391-404.

Amnesty International, ‘Afghanistan' No One Listens to Us and No One Treats Us like Human Beings: Justice Denied to Women' ASA 11/023/2003 http://www.amnesty.org/en/library/info/ASA11/023/2003, at 28 August 2007.

Benhabib, S, The Claims of Culture: Equality and Diversity in the Global Era, Oxford, Princeton University Press, 2002.

Bahramitash, R, 'The War on Terror, Feminist Orientalism and Orientalist Feminism: Case Studies of Two North American Bestsellers,' Critique: Critical Middle Eastern Studies (2005) 14:2 221-235.

Brems, E, 'Enemies or Allies?: Feminism and Cultural Relativism as Dissident Voices in Human Rights Discourse.' Human Rights Quarterly (1997) 19(1) 136-164.

Carens, J, Culture, Citizenship and Community: A Contextual Exploration of Justice as Evenhandedness. Oxford: OUP, 2000.

Dembour, Marie, 'The Cases That Were Not To Be: Religious Freedom and the European Court of Human Rights' in Italo Pardo (ed.) Morals of Legitimacy: Between Agency and System. Oxford: Berghahn Books, 2000.

Dembour, M, Who Believes in Human Rights?:The European Convention in Question. Cambridge: CUP, 2006.

Public Space: The Journal of Law and Social Justice (2009) Vol 4, pp 34-73 
De Sousa Santos, Bonaventura and Cesar a. Rodriguez-Garavito, Law And Globalisation from Below, Towards Cosmopolitan Legality. Cambridge: Cambridge University Press, 2005.

DFID (Department for International Development), Realising Rights for Poor People, London: DFID, 2000.

http://www.globalissues.org/HumanRights/WomensRights

European Commission Against Racism and Intolerance (ECRI), ECRI General Policy Recommendation No 5, On Combating Intolerance and Discrimination Against Muslims, Adopted 16th March 2000. Strasbourg 2000. http://www.coe.int/t/dghl/monitoring/ecri/activities/gpr/en/recommendation_n5/Rec5 en21.pdf

European Union Monitoring Centre, Racism and Islamophobia in the Member States of the EU, December 2006, http://fra.europa.eu/fra/material/pub/racism/report-racism0807-en-pdf at 4 September 2007.

Falk, R, 'Orientalism and International Law: A Matter of Contemporary Urgency' The Arab World Geographer (2004) 7 (1-2) 103 -116.

Fautre, W, 'The Sect Issue in France and Belgium' in Davies, D and G Besier (eds) International Perspectives on Freedom and Equality of Religious Belief, J.M.Dawson Institute of Church- State Studies, Baylor University, 2002.

Gibson, N, 'Faith in the Courts: Religious Dress and Human Rights,' Cambridge Law Journal (2007) 66 (3), 657.

Human Rights Watch, Memorandum to the Turkish Government on Human Rights Watch's Concerns with Regard to Academic Freedom in Higher Education, and Access to Higher Education for Women who Wear the Headscarf (Human Rights Watch Briefing Paper June 29, 2004) http://www.hrw.org/legacy/backgrounder/eca/turkey/2004/index.htm 
Human Rights Watch, Discrimination in the Name of Neutrality: Headscarf Bans for Teachers and Civil Servants in Germany, 2009 Discrimination in the Name of Neutrality I Human Rights Watch at 20 March 2009.

IHF 'A French Ban on Religious Symbols Would Violate International Protection of Freedom of Religion.' (2007) http//www.ihf-hr.org. at 4 September 2007.

Jahangir, Asma (Special Rapporteur on Freedom of Religion or Belief) Civil and Political Rights, Including the Question of Religious Intolerance, Economic and Social Council E/CN.4/2005/61 20 December 2004.

Jahangir, Asma, (Special Rapporteur on Freedom of Religion or Belief) Civil and Political Rights, Including the Question of Religious Intolerance: E/CN.4/2006/5 9 January 2006.

Jahangir, Asma, (Special Rapporteur on Freedom of Religion or Belief) Implementation of General Assembly Resolution 60/251 of 15th March 2006 Entitled 'Human Rights Council' A/HRC/4/21 26 December 2006.

Kabeer, N, 'Globalisation, Labour Standards, And Women's Rights: Dilemmas of Collective (In) Action in an Interdependent World' Feminist Economics 2004 10(1) 3-35

Marshall, P, 'Religious Freedom' in Liam Gearon (ed.) Human Rights and Religion: A Reader. Brighton: Sussex Academic Press, 2002.

Kapur, R Erotic Justice: Law and the Politics of Postcolonialism, Glasshouse Press, London, 2005.

Kerr, J and C Sweetman, 'Editorial,' Gender and Development (2003)11 (1) 3-12. 
Massell, G, 'Law as an Instrument of Revolutionary Change in a Traditional Milieu: The Case of Soviet Central Asia' 2 Law and Society Review (1968) 179-228.

McClintock, A, Imperial leather: race, gender and sexuality in the colonial contest. London: Routledge, 1994.

Midgely, C, (ed) Gender and Imperialism. Manchester: Manchester University Press, 1998.

Midgely, C, ‘ British Women, Women's Rights and Empire, 1790 -1850' in Grimshaw, Holmes and Lake, Women's Rights and Human Rights in International Historical Perspective. Basingstoke: Palgrave, 2001.

Mohanty T, C, 'Under Western Eyes: Feminist Scholarship and Colonial Discourses' Boundary (1984) 12 (3) 333-358.

Moon, Gay, 'The Draft Discrimination Protocol to the European Convention on Human Rights: A Progress Report' (2000) 1 European Human Rights Law Review 49-53.

Okin, S, M, 'Feminism and Multiculturalism: Some Tensions.' Ethics (1998) 108(4). 661-684.

Onar, N 'Freedom of Religion vs. Secularism?: Universal Rights, Turkish Islamism, and the Headscarf' RAMSES Working Paper 8/07 April 07 European Studies Centre of Oxford.http://www.sant.ox.ac.uk/esc/ramses/onar.pdf at November 2008.

Overy, C and R White, Jacobs and White: European Convention on Human Rights. Oxford: Oxford University Press, 2002.

Painter, G, 'Linking Women's Rights and MDG's: An agenda for 2005 from the Gender and Development Network' Gender and Development (2005)13 (1) 79- 93. 
Pettman, Jan Jindy 'Global Politics and Transnational Feminisms,' in Feminist Politics, Activism and Vision: Local and Global Challenges, ed. L Ricciutelli, A. Miles and M. McFadden, London and New York: Zed Books, 2005, pp. 49-63.

Phillips, A, Multiculturalism without Culture. Woodstock: Princeton University Press, 2008.

Poulter, S, Ethnicity, Law and Human Rights: the English Experience. Oxford: OUP, 1998.

Randriamo, Zo 'African Women Challenging Neo-Liberal Economic Orthodoxy: The Conception and Mission of the GERA Programme' Gender and Development (2003)11(1) 44-55.

Ratna K. Erotic Justice: Law and the Politics of Postcolonialism. London: Glasshouse Press, 2005.

Razack, S, ‘The 'Sharia Law’ Debate In Ontario: The Modernity/ Premodernity Distinction in Legal Efforts to Protect Women from Culture.' Feminist Legal Studies (2007) 15:3-32.

Said, Edward, Orientalism: Western Conceptions of the Orient. London: Penguin, 1978.

Stewart, A, 'Globalising Gender Justice?’ Law, Social Justice and Global Development Journal (2007)1 http://www.go.warwick.ac.uk/elj/lgd/2007_1/stewart at 1 October 2008.

Thompson, Ann, Barbary and Enlightenment: European Attitudes towards the Maghreb in the Eighteenth Century. Leiden: Brill,1987.

Tripp, A, 'Challenges In Transnational Mobilisation' in Tripp, A and m. Ferree (eds) Globalism Feminism: Transnational Women's Activism, Organizing and Human Rights. New York: NYU Press 2006, p.299.

Public Space: The Journal of Law and Social Justice (2009) Vol 4, pp 34-73 
Uitz, R , Freedom of Religion In European Constitutional and International Law. Strasbourg: Council of Europe Publishing, 2007.

Wallach , J, The Politics of the Veil. Princeton: Princeton University Press, 2007

Weber, C, 'Unveiling Scheherazade: Feminist Orientalism in the International Alliance of Women, 1911- 1950,' Feminist Studies (2001) 27:1 125- 15.

Williams, M, Voice, Trust and Memory : Marginalized Groups and the Failure of Liberal Representation. Princeton: Princeton University Press, 2000.

World Bank, Engendering Development: Through Gender Equality in Rights, Resources and Voice. Washington: World Bank, 2001.

Yeğenoğlu, M, Colonial Fantasies: Towards a Feminist Reading of Orientalism. Cambridge: CUP, 1998.

Youmans, William Lafi, 'Edward Said and Legal Scholarship' 3 UCLA Journal of Islamic and Near Eastern Law (2004) 107 1- 11.

\section{Other Sources}

Cedaw Committee - Concluding Comments By the Committee on the Submission of Country Report CEDAW/C/TUR/CC/4-5

CEDAW/PSWG/2005///CRP:1/add.8 pre-session working group for the 32 session 10-28 January http://www.un.org/womenwatch/daw/cedaw/cedaw32/concludecomments/Turkey/CEDAW-CC-TUR-0523813E.pdf at 4 September 2007.

Committee on Equality - Council of Europe (2005) Parliamentary Assembly Resolution 1464, October 2005.

Http://assembly.coe.int/Documents/AdoptedText/ta05/ERES1464.htm at 10 November 2007

Public Space: The Journal of Law and Social Justice (2009) Vol 4, pp 34-73 
Council of Europe Press Release, Issued By The Registrar, 'Chamber Judgements Concerning Greece, Italy, Russia, Slovenia, and Turkey' 245, 27.4.2006 http://www.echr.coe.int/Eng/Press/2006/April/Chamberjudgments270406.htm at 1 October 2008.

\section{Cases Referred To}

Dahlab v Switzerland 42393/98 15 January

2001http://www.law.yale.edu/documents/pdf/Intellectual_Life/Dahlab_v_Switzerland .pdf at 1 October 2008.

Gundez v Turkey (Application no. 3507/97) 4 December 2003

http:/cmiskp.echr.coe.int/tkp197/viewhbkm.aspsessionID=15331725? at 1 October 2008.

Hudoyberganova V Uzbekistan, Communication No. 931/2000 UN Doc.

CCPR/C/82/D/931/200 (2004). University of Minnesota Human Rights Library (with Ruth Wedgewood's dissent) http:/www1.umn.edu/humanrts/undocs/html/931$20000 \mathrm{html}$ at 1 October 2008.

Hudoyberganova vUzbekistan, Communication No. 931/2000 UN Doc. CCPR/C/82/D/931/200 (2004). (without Ruth Wedgewood's dissent) 931/2000Http://sim.law.uu.nl/SIM/CaseLaw/fulltextccpr.nsf/160f6e7fb318e8c1256d4 10033 e... at 1 October 2008.

Rahime Kayhan v Turkey, CEDAW/C/34/D/8/2005Decision of the Committee on the Elimination of Discrimination against Women under the Optional Protocol to the Convention on the Elimination of All Forms of Discrimination against Women (thirty-fourth session) Communication No.- 8/2005 http://www.bayefsky.com/pdf/turkey_t5_cedaw_8_2005.pdf at 28 February 2009. 
MC v Bulgaria, Application no 39272/98) 2003

http://www.coe.int/t/e/legal_affairs/legal_co-

operation/fight_against_sexual_exploitation_of_children/1_pc-

es/CASE\%20OF\%20MC\%20v.\%20BULGARIA.pdf accessed August 2007.

Opuz v Turkey Application 33401/02 9th June 2009

http://www.coe.int/t/dghl/standardsetting/violence/Opuz v Turkey.pdf at 20 June 2009.

$\mathrm{R}$ (on the application of Begum ( by her litigation next friend, Rahman)) (Respondent)

v. Headteacher and Governor of Denbigh High School ( Appellants) [2006] UKHL

15http://www.publications.parliament.uk/pa/ld200506/ldjudgmt/jd060322/begum.pdf at 1 October 2008.

R (on the application of Shabena Begum) V Denbigh High School (Court of Appeal stage) SB, R (on the application of) v Denbigh High School [2005] EWCA Civ 199 (02 March 2005)

Sahin v Turkey, Application 44774/98 Chamber judgment decision 8th of June 2004 Sahin v. Turkey

Sahin v Turkey (Application no 44774/98) to Grand Chamber Strasbourg 10 November 2005, http://portal.coe.ge/downloads/Judgments/LEYLA SAHIN v TURKEY.pdf at 10 January 2006. 